UDC 811.161.2’367.332

DOI $10.15421 / 462005$

\title{
THE SYNTACTIC UNIT (FROM DEFINITION TO MODELLING)
}

V. Koroliova

Doctor of Philological Sciences, Associate Professor,

Head of the Department of Ukrainian Language,

Oles Honchar Dnipro National University

valeria.korolyova2015@gmail.com orcid.org/0000-0002-7482-0517

I. Popova

Doctor of Philological Sciences, Professor, Dean of the Faculty of Ukrainian and Foreign Philology and Study of Art, Professor of the Department of Ukrainian Language,

Oles Honchar Dnipro National University dekanat fuifm@i.ua orcid.org/0000-0003-1423-2358

Introduction. In the present linguistic science, a point is considered to be indisputable that in the course of time the total amount of substantial and conceptual studies increases, in particular the studies in the field of syntax, in spite of the fact that this scientific branch was formalized as the separate linguistic subject (in its contemporary comprehension, of course) later than the other language layers. It is syntax that represents the top level of language organization, has its own language chains as the communicative creations in its competence and attracts a lot of different collisions. It is exactly this part of linguistics that is distinguished probably with the most essential discussions, conceptions, comments and diversity of opinions about any language phenomena. Taking it into consideration, such basic categories as the syntactic unit, the syntactic connection and the syntactic model are not the exceptions either.

The aim of the proposed scientific survey is to attempt to interpret carefully one of these basic concepts, namely the syntactic unit, in context of the system approach to the comprehension of the syntactic level of language as a base for the different aspects of the syntactic unit - formal and syntactic, semantic and syntactic, functional and communicative.

The aim stipulates the fulfilment of the following main tasks:

- to survey the results in the treating of such syntactic construct as the unit;

- to analyse the available definitions of the syntactic unit as one of the basic syntactic concepts in context of the terminological system of modern syntax;

- to propound a definition of the syntactic unit as one of the substantial categories of syntax adjusted for the structural and functional peculiarities of the defined object;

- to describe a system of syntactic units in the present Ukrainian language as the hierarchical sequence of basic, cardinal, derivative, analytical, analytical and search constructs;

- to characterise the general principles of construction of linguistic models and the procedure of modelling of essential syntactic units in the Ukrainian language on the basis of operations of reflection and contamination.

Methods and methodology of investigation. In the process of substantiation of class status of the syntactic unit we base ourselves upon the fundamental theoretical and methodological principles of researches in present Ukrainian and general linguistics, especially upon the statements about the system of the language and speech phenomena. The principal methodological substratum in the opening of the essence of the syntactic unit as the fundamental category of syntax is the use of the methods orientated to the investigations, the description and the analysis of the syntactic phenomena in context of the general system of the Ukrainian language. The methods of observation and description, which allowed to analyze thoroughly the level of metalanguage treatments of the examined phenomenon, were used for a comprehensive study of the essence of the definition and 


\section{Ukrainian sense. 2020. ISSN 2313-4437}

the status of the syntactic unit. The analysis of the lexical definitions has become the auxiliary one. It has been built the hierarchical system of the basic, essential, derivative, analytical, analytical and searchable syntactic units in consequence of the modification and the combination of the methods of generalization, comparison and systematization. The methods of transformation and modelling have been used for the representation of the authors' interpretation of some separate displays of the essence of the syntactic unit as well as the patterns of the cardinal syntactic units.

Results and discussion. The point of departure of the syntactic theory in any language is that one that, while defining its subject, the linguists emphasize, as usual, two principal components of the direct object in the corresponding scientific searches: the language and speech formation, qualified as the syntactic units, and the processes, linked with the creation and the operating of these units, i.e. the mechanisms of the speech formation (Akhmanova, 1966; Vykhovanets, 2000; Hanych \& Oliinyk, 1985; Zahnitko, 2001; Zubkov, 2004; Karpenko, 2006; Shulzhuk, 2004; Koroliova 2016 et al.).

The problems of metalanguage of syntax are remained, in any case, within eyesight of the linguists who study and describe the grammatical system of the language. While fixing one or another syntactic phenomenon, the linguists despite to demonstrate maximally the essential parameters in the corresponding definition, to reflect fully the structural and functional peculiarities or to show the parameters together with the peculiarities at once. The lexeme definition in its usual and general use means "the brief logical determination that contains the most substantial signs of the defined notion" (Busel, 2005:290). We add that if it comes to defining the term, some scientific category, when it is impossible to use the alternative interpretation a priori, it is necessary to take into consideration at least three requirements. Firstly, the formulation must be exact and strictly correspond to the defined realia in any their manifestations; secondly, it is essential to rely on the clearly determined and perceived notion; thirdly, it is important to be distinguished by the adequate differential potency. The sense of the last requirement is that, on the one hand, proceeded on the specific definition, it is possible to oppose this term, this category to any other phenomenon, but on the other hand - to qualify it as the sought-for, not leaving any special case without attention. Taking above-stated into account, we will try to specify clearly the unit as the linguistic phenomenon and, correspondingly, to define the syntactic unit as one of the fundamental categories of syntax, that, in its turn, is the linguistic unit. The most common interpretations of the lexeme unit are as follows: "The independent part included in the whole" (Hodyul, 2000: 199) or "the separate part of something that forms the relatively independent whole" (Busel, 2005: 828). There are broader and more concretized definitions of the unit in the dictionaries of linguistic terms (look: Akhmanova, 1966: 146; Hanych \& Oliinyk, 1985: 161; Yartseva, 1990: 149 et al.).

The most typical and standard definitions of the syntactic unit have the different accentuation ad modum: "The syntactically organized and communicatively independent part of the larger expression or the separate expression that has the definite syntactic structure and the communicative independence" (Hanych \& Oliinyk, 1985: 161), "The unit of the syntactic level of language that is distinguished on the basis of syntactic connections and syntactic relations" (Rusanivckyi \& Taranenko, 2000: 550), "The elements of the syntactic system of language that define the language's specificity" (Stoliarova, Prystaiko \& Popko, 2003: 110).

Thus, having made the definite generalizations about the syntactic unit, it is possible to form the corresponding definition as the metalanguage category of syntax. The essence of these generalizations is as follows:

1. The syntactic unit represents the separate syntactic part of some whole or is the whole that has its own plane of content and expression and is nominated somehow or other.

2. The syntactic unit is, first and foremost, the unit of its own syntactic level, with the characteristic relations both on its layer of language structure and in the interaction with the constructs of other language levels.

3. The syntactic unit is mainly some expression or the part of expression, i.e. the definite speech chain or its fragment, that are grammatically regulated and marked in a functioned way as the communicative formations. 


\section{Ukrainian sense. 2020. ISSN 2313-4437}

Thus, concepts such as the speech chain, grammatical ordering, and functional marking become crucial in defining a syntactic unit. A speech chain is any flow, any sequence of words, including a single word, if it is somehow put emphasis on, isolated or functionally loaded. The grammatical ordering of the speech chain presupposes the existence of certain grammatical or semantic-grammatical relations between its components and their grammatical connection by all means. Any linguistic unit must be functionally significant. Taking everything into account, the syntactic unit can be interpreted as a functionally marked and grammatically ordered speech chain, which is a free semantically significant sequence of word formation, or even a separate word form.

Such a definition makes it possible to classify any speech formation as a syntactic unit, where there is a plan of expression (grammatical means of communication) and a plan of content (information of a semantic or functional nature). Therefore, a syntactic unit can be a structure from what is called Larger-then-the-sentence to a simple lexical component. For example, Larger-thenthe-sentence When Halyna Kalchenko was working in marble, there was the roar in the workshop. In order not to be deafened, she put on a tank helmet. And then she became like Pallas Athena. The working goddess. Most of all, she loved marble, this noble material that emits light and whiteness (Honchar, 2008: 302) has five sentences, four of which are communicatively insufficient without the first one due to their structural ellipticity and semantic uncertainty. However, these sentences are attached to the first sentence to complete the topic and specify what is called an opening sentence. Here the formal linguistic means of communication of the sentences of the mentioned Larger-then-the-sentence, which include the parallelism of morphological forms of the predicate (worked, put on, became, loved) and, undoubtedly, the chain pronoun connection between the subjects of the first and fifth sentences, clearly manifest themselves. (Halyna Kalchenko and she). A syntactic unit can be a simple lexical component of the speech chain, even a bond such as, for example, a minimal co-ordinate conjunction in its physical form and, which is also functionally marked and meaningful, as it is one of the means of syntactic communication of speech chain components and indicates grammatically equal (connecting, enumerative) relations between components, for example:... Kyiv, Uman, and Haisin... remained behind us (Honchar, 2008: 315).

The given examples show us grammatically ordered sequences of words or separate words with the expressed functions and the certain content. However, the nature of grammatical ordering, their functions and the degree of linguistic significance are different in terms of their both content and expression. This fact arises the need for grading syntactic units, first of all, in terms of the importance of hierarchical relations between them.

Summarizing our work in researching this issue (Popova, 2009; Popova, 2013; Popova, 2014; Popova, 2016), we consider it appropriate to distinguish four subsets: basic, main, derivative and peripheral, which, in turn, are divided into analytical subsets and analytical and searching ones.

Basic (peculiar universals) are two units - a word (as a simple, minimal lexical component of the speech chain) and a construction (as a certain sequence of words that is a speech chain). They are the substantial basis for all syntactic units and, initially, for the most important link - the system of basic syntactic units.

Regarding the affiliation of syntactic formations to the basic syntactic units in linguistics, there are different concepts, sometimes quite different from each other. For example, here are just a few of them. There is an opinion that the main, central unit of syntax is a sentence (Peterson, 1923; Fortunatov, 1956) or, according to I. Revzin, it is called the main speech unit (MSU) (Revzin, 1962). A two-component system with different variations of components is quite common: a word and a sentence (Bilodid, 1972), phrases and sentences (Akhmanova, 1966; Hanych \& Oliynyk, 1985; Krotevych \& Rodzevych, 1957, etc.). In the three-component system (the most common) there are also variable elements: a word, a phrase, a sentence (Solganik, 1973), a minimal syntactic unit, a phrase, a sentence (Zagnitko, 2001; Shulzhuk, 2004), a word form, a phrase, a sentence (Belyaev, 2003) and a phrase, a sentence and a complex sentence (Levitsky, 1983). Gradually, linguists moved to a four-component system: a minimal syntactic unit, a phrase, a sentence, Largerthen-the-sentence (Zagnitko, 2001), a word, a phrase, a sentence and a complex sentence (Beloshapkova, 1967). The five-component system of the main syntactic units includes a word, 


\section{Ukrainian sense. 2020. ISSN 2313-4437}

a word form, a phrase, a simple and complex sentence (Russian, 1980) or a word, a phrase, a sentence, a complex sentence and a text (Sirotinina, 1980). Even a far from complete list of systems of the main syntactic units does not allow motivating any preferences of any of them. In our opinion, it is possible to form a system of syntactic units only taking into account certain criteria and parameters, namely: adequacy to the grammatical structure of the Ukrainian language; functional determination; the maximum possible generalization within the performed functions; completeness and self-sufficiency; connection with other units of the whole system (Popova, 2009: 104-105). In view of this, our proposed system of the main syntactic units covers six components: a word form, a phrase, a word combination, a sentence, a text and Larger-then-the-sentence.

A word form is a structurally minimal syntactic unit that functions either as a communicatively significant component of a certain speech chain (for example, any member of a sentence, core or dependent component of a phrase), or as an independent syntactic formation (a whole sentence like Evening (Honchar, 2008: 149); Sorror (Honchar, 2008: 290), or even the text, if it is the name of a sign of any institution or enterprise such as "Bath").

The traditional syntactic unit is a word combination. However, a careful reading of its definition reveals a certain contradiction in defining the essence of this phenomenon. Therefore, certain syntactic phenomena, which linguists belong only to the phrase, should be distinguished by giving them a different name.

Thus, in our opinion, a word phrase is a combination of two or more full words (word forms) based only on a subjunctive correlation (the book read, read a book, etc.).

To nominate a combination of two or more full words based on a subordinate or another semantic-grammatical relationship that is not actually a subjunctive one, we propose the term a word connection (books and notebooks, read or write). This can be a construction that is a predicative basis of a sentence, the components of which are connected by coordination, actualizing the predicative relations in the speech chain, for example: Such associations are given by life (Honchar, 2008: 232). Thus, a word-interconnection is opposed to a word-combination as a nominative syntactic unit, which expresses, like a word, one concept, although it is split and enriched in its meaning at all events. This opposition eliminates the contradiction behind the interpretation and definition of the word-combination as a syntactic unit.

Undoubtedly, the greatest attention of linguists is drawn to such a syntactic unit as a sentence with its almost unregulated communicative possibilities and extraordinary structural diversity. Being unable to consider those parameters of this syntactic phenomenon that are most often emphasized (the formation according to the laws of a particular language, integrity, expression of a complete thought, etc.) in detail within one article, we note that the differential features of this syntactic unit by its nature are the three most important: predicative, communicative and functional. They are these features that form the categorical plan of the sentence, and this plan, but not the plan of content and expression, should be the basis for the interpretation of the sentence and its definition. Predicativity is the most general concept in terms of the relation of the reported to reality, communicativeness is the fundamental ability to perform an act of communication, and functionality involves the introduction of a certain syntactic construction in the real process of communication to perform a communicative task. Considering everything, a sentence can be defined as a certain predicative syntactic formation, consisting of a word (or its analogue) or a syntactically related group of words (or their analogues) and performs a communicative function.

These are the features that form the categorical plan of the sentence, and it, in its turn, rather than the plan of content and expression, should be the basis for the interpretation of the sentence and its definition. Predicativeness is the most general concept in terms of the relation of the reported to reality, communicativeness is the fundamental ability to perform an act of communication, and functionality involves the introduction of a certain syntactic construction in the real process of communication to perform a communicative task. Having considered all the above-mentioned, a sentence can be defined as a certain predicative syntactic formation, consisting of a word (or its analogue) or a syntactically related group of words (or their analogues) and performing a communicative function. 


\section{Ukrainian sense. 2020. ISSN 2313-4437}

Similarly, categorical parameters allow you to reflect the essence and create or choose an acceptable definition for such a construct as text. These parameters are, as in the sentence, communicativeness with the same meaning, as well as pragmatism and completion - its specific characteristics, among which pragmatic guidance is essential, mandatory (but it can accompany, in particular, the sentence and Larger-then-the-sentence), and semantic completion, which is the absolute differential feature of this syntactic unit. Thus, the text is a certain communicatively significant, formally and semantically complete speech formation, built with a certain pragmatic instruction. Interpretation of Larger-then-the-sentence in the proposed scientific research is common, because this concept means a combination of two or more sentences that are interconnected by formal linguistic means of lexical or grammatical nature and united by a common theme, a guide to the content of a separate act of communication.

In the given system of basic syntactic units, word-form, word-combination, word-unity, and Larger-then-the-sentence are determined structurally and clearly opposed by their differential features, whereas sentences and text are characterized by categorical parameters, without being regulated by anything structurally. In this way the system of basic syntactic units becomes complete, because in its terms it is possible to qualify any speech chain and any grammatically significant fragment of it, and most importantly, that its components are a holistic structural and systemic formation of interconnected and interdependent units of the syntactic language level. The main syntactic units are qualified as conceptual categories, i.e. those that form the basis of the general concept of studying and describing the syntactic system of a particular language, including Ukrainian.

Undoubtedly, all the main syntactic units specify and distribute between different subclasses according to their functional and structural characteristics within a certain syntactic construction.

These units are related to operational categories, their system is mobile in its peripheral part and is constantly changing. It can be reduced, expanded or completely rebuilt depending on the nature of the tasks in the parsing process. This is how derivative syntactic units are formed, which are formed from each of the basic ones as a separate grammatical category due to their derivational detailing. It is clear that at the level of operational syntactic categories any, even the most original, most unexpected approach to the analysis of the syntactic system of the Ukrainian language is interesting and noteworthy, and consequently the emergence of an infinite number of different speech chains that are syntactic units and consist of syntactic units. However, it seems expedient to further detail the basic syntactic units on the principles of introducing derivatives into the metalanguage of Ukrainian syntax, which are based on their objective and formally expressed properties.

The formation of derived units can be illustrated by the example of a word form as the least considered in syntactic theory. The word form is unambiguously determined in structural terms, but its functional plan is the broadest. It accordingly acts as a functionally significant and structurally necessary component of the word combination (autumn morning, to relax in the evening), the word connection (to work and to relax, morning and evening), the sentence ( $I$ am working on a new novel) (Honchar, 2008: 358), as well as the function as separate sentence, for example, the first in this construction: Yerevan. For the first time in my life I see Ararat. It was that one, indeed. (Honchar, 2008: 53) or text ("Hairdressering salon") (inscription-plate on the door of the institution) or is a part of a sentence in a large syntactic sequence (Taras's Willow. Dugout. Stone well, narrow, deep as a trumpet. This is all that is left of him) (Honchar, 2008: 93).

A word form as a derived syntactic unit can be detailed depending on which syntactic construction it belongs to and what of its component it is. A word form is a component of a word combination, a word connection and a sentence.

The general system of derivatives of the word form can be represented as follows. Initially, it is divided into two classes: the main component of the speech chain and the function one. Among the main components at the second level of derivation we distinguish the member of the sentence, the component of the word combination and the word-unity, and then the members of the sentence are classified as primary (predicative basis) and secondary (distributors), the components of the 


\section{Ukrainian sense. 2020. ISSN 2313-4437}

word combination - core and dependent. Further detailing of word-form derivatives is also possible, but it is correlated either with some syntactic concept or with a transition to another language level. For example: the specification of the main limbs as derivative syntactic units depends on the adoption of at least one of the three concepts of forming the predicative basis of the sentence and building a system that includes either one main limb of the sentence (predicate or its analogue and the top of the dependency tree), or two (subject and predicate), or, finally, three (subject, predicate and the main limb of a single sentence). The function component of the speech chain has only three derivatives of the next level of derivation - clamp, share and introduction. The core and dependent components of the word combination, word-unities and the clamps are most likely to exhaust their syntactic resources at this level of derivation. It should be noted that the declared system of word derivatives is not a standard and remains open.

According to a certain pattern, derivative units are formed from other basic ones - word combinations, word unities, sentences, text and Larger-then-the-sentence, which can be the subject of a separate scientific research.

A certain place in the system of syntactic units is occupied by analytical and analytical and search units, formed as a result of concretization of derivatives.

Analytical units are built on the basis of categories of traditional formal and grammatical syntax, and they include sentence limbs, different types of word combinations by semantic and morphological characteristics of their components, types of subordinate clauses and so on.

Analytical and search syntactic units can be distinguished in the context of certain new, original concepts as opposed to classical syntax, such as theme and rhyme, constructive centers and distributors, semantic categories of attributes, etc. Usually these units in the process of analysis of speech chains either remain in the metalanguage of syntax, becoming basic or derivative, or are discussed, or cease to attract the attention of linguists.

Syntactic units are a huge, even theoretically innumerable set of various constructions. It is almost impossible to comprehend them fully and set an exact list. This primarily led to the emergence in the practice of parsing of speech chains of a special and optimally effective methodthe method of linguistic modelling.

The need to model syntactic units is more than obvious, because it is impossible to count, organize and list all the syntactic constructions of the Ukrainian language, as well as any other of the developed languages of the world, neither theoretically nor practically.

In modern linguistic modelling, three hypostases of the concept model have been actualized: a structural or functional analogue of the studied phenomenon; a kind of metalanguage, that is, a system of certain rules within the framework of which a researcher studies the grammar of a language and formulates the results of his research; a specific linguistic unit. The essence of linguistic modelling lies in the use of two operations: reflection as a metalanguage universality and contamination of images, which allows generalizing models of various structures of a given type in one analytical expression. The latter operation was introduced into the practice of linguistic research by I. Menshikov, who built an analytical model of contaminated images (Menshikov, 1969; Menshikov, 1972). In general, all syntactic models are divided into two main classes: graphical and analytical. They arise as a result of the application of the display operation, however, the latter - on the basis of the contamination operation. In Ukrainian studies, there is a certain experience in modelling syntactic units, although it is rather sporadic. Being based on the proposed general typology of these syntactic constructions, it has three levels, precommunicative level of the model of word form, phrase and word combination are stated at the first, sentences as the main communicative unit are stated at the second, at the third - supraphrasal unity and text.

The model of a word form is its symbolic representation as a result of the reflection operation; it is one of the prerequisites for modelling units of the precommunicative level, that is, phrases and word combinations. For example, in analytical models, the word form is mainly presenteded by the symbol of the paradigmatic class (part of speech) which it belongs to, or syntagmatic (sentence member), and therefore, in accordance with the performed function. It is clear that the modelling of word forms outside of links with other ones is accompanied by 


\section{Ukrainian sense. 2020. ISSN 2313-4437}

information updated using suprasegmental means or indices. For example, models of the phrase happy day and happy with success, filled with the same paradigmatic classes (Adj is an adjective, $\mathbf{N}$ - a noun), can be opposed to each other by various modelling of their components, so that: underline the core word (Adj $\mathbf{N}$ and Adj $\mathbf{N}$ ), put the core word first ( $\mathbf{N}$ Adj and Adj $\mathbf{N}$ ), indicate with an arrow the direction of the contractual connection ( $\mathbf{A d j} \rightarrow \mathbf{N}$ and $\mathbf{A d j} \leftarrow \mathbf{N}$ ), mark with an index (c) the core word (AdjNc and Adje N), etc.

The word combination model is being built using a certain sequence of symbols, primarily symbols of word forms, noting the syntactic links between them, as well as the sequence of location.

For example, a graphical model of an elementary phrase like the done work can be represented as follows , and the analytical model in accordance with the AdjN.

The structural organization of the word combination and word connection are almost identical. Both of these constructions are freely combined and are included in each other without any theoretical regulations, without resorting to any specific metalanguage constructions. The peculiarity of the graphic model of word connection (while modelling word connection, the operation of contamination is NOT used), is that at least two components are connected in this construction and qualified as core words. Such a construction can be a combination of two or more significant words on the basis of a compositional connection, structural analogs of the predicative basis, the two-part sentence, caused by some reasons, it turned out to be in the pre-communicative functional field. Examples of graphic patterns of phrases like teacher and students, study and work, funny and sad, etc

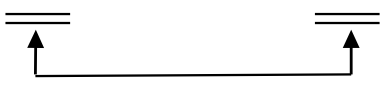

The graphical model of phrases like creative teachers and inquisitive students will be somewhat different; study during the day and work in the evening; very funny and not entirely sad, etc .:

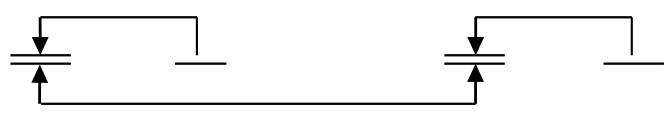

So, with the help of a graphical model, you can describe the structure of word formation adequately.

It should be noted that in modern Ukrainian studies, while modelling the structure of a proposal, they most often use not the term model, but the term structure scheme of the sentence, moreover, mainly only for a simple sentence. However, structural schemes inherently do not model sentences as a linguistic unit, because they can only be called models of the predicative core of a sentence at the best. At the same time, any procedural restrictions on the modelling of syntactic units and, in particular, such as a sentence with its structural indeterminacy and quantitative inexhaustibility, narrow the representative potential of the model, reduce the volume of speech material related to it. Taking this into account, "the actual procedure for constructing a sentence model should be clearly outlined in its metalanguage aspect, should ideally be focused both on modelling the sentence as a whole and building an analytical expression common for any communicative unit, and modelling a certain class of sentences and building a number of analytical expressions, each of which represents some type of sentences, simple or complex, two-part or onepart ones and etc." (Popova, 2009: 347).

So, in the real field of subject knowledge on the syntactic stage of the structure of the Ukrainian language, the sentence model as a linguistic unit should have clear basic parameters in order to oppose the analytical expressions proposed by us to the description of the sentence syntax in terms of its structural schemes. These parameters assume: 


\section{Ukrainian sense. 2020. ISSN 2313-4437}

- the structure of a sentence as a syntactic unit must be described in terms of syntagmatic classes (sentence members or their analogues);

- the sentence model is simultaneously correlated with its linguistic prototype or a certain set of such prototypes;

- in the sentence model, all its grammatically significant structural components are recorded within the selected material;

- the sentence model is a structural analogue not only of a specific syntactic structure, but also of any of its varieties in general or within a certain class of communicative units;

- an analytical model of a sentence, if necessary, is built, taking into account the syntactic characteristics of its prototypes.

The maximum generalization of the sentence model, provided that the required degree of its adequacy is followed, makes it possible to combine its three components in the modelling process: operations of contamination of images; syntagmatic word class systems; the possibility of transition to this system from both paradigmatic classes and paradigmatic phrases.

Syntagmatic classes, on the basis of which the model is built, have been represented by their two ranks. Syntagmatic classes of the first rank are constructive centers of a sentence, combining three components: $\mathbf{A}$ - subject, $\mathbf{B}$ - predicate, $\mathbf{C}$ - the main member of one-part sentences. Words and syntactically related groups of words, directly subordinate to the constructive centers of the sentence, are syntagmatic classes of the second rank. They represent a five-component system, which includes a substantive component: a noun, a substantive pronoun and a cardinal numeral, as well as the paradigmatic phrase (a) formed by them of an adjective component: adjective, adjective pronoun, ordinal numeral and participle, as well as the corresponding paradigmatic phrase (b); adverbial: adverb, gerunds and formed phrases (c); infinitive: subordinate to any of the main members of the infinitive or infinitive construction (d); predicative component, that is, the subordinate clause (e). Thus, while constructing a sentence model, in addition to the image of the predicative basis, the components of this basis must be introduced to it. And this is the most essential in the process of modelling a sentence as a syntactic unit, since it helps to qualify the corresponding expression precisely as a model of the entire syntactic unit, the whole sentence, and not some of its separate components or fragments. In this case, using the operation of contaminated images, the models of individual types of sentences can be combined into their general model.

In this case, the models of separate sentence types can be combined into their general model by the operation of contaminated images. Here are some examples of the model of simple sentences: Ingenious observation (Honchar, 2008: 65) - a C; Listened to young poets of Luhansk region (Honchar, 2008: 78) - C a; But there is still a lack of significance of thought (Honchar, 2008: 78) - c C a; Green everywhere (Honchar, 2008: 186) - C c; And we return to Kyiv (Honchar, 2008: 190) - C c; Sorry for him (Honchar, 2008: 191) - C a; Saw the Mona Lisa in the Pushkin Museum (Honchar, 2008: 191) - C a c.

The models of double sentences: The soul sometimes misses people in white shirts (Honchar, 2008: 57) - ${ }^{\mathbf{A}} \mathbf{c} \mathbf{B}$ a; And they are still there (Honchar, 2008: 58) - ${ }^{\mathbf{A}} \mathbf{B} \mathbf{c}$; The world is experiencing the rise of dictatorships (Honchar, 2008: 63) $-{ }^{\mathbf{A}} \mathbf{B} \mathbf{a} ;$ Also Shiyan responded enthusiastically (Honchar, 2008; 63) ) - c B ${ }^{\mathbf{A}}$; Golden apples of churches burn in the sky (Honchar, 2008: 67) B c a A.

The graphical variant of sentence models is a tree of dependencies (for a simple sentence) and a linear scheme (for a complex one). For example, a graphical model of a simple sentence Each bears the glare of the sun (Honchar, 2008: 223) is:

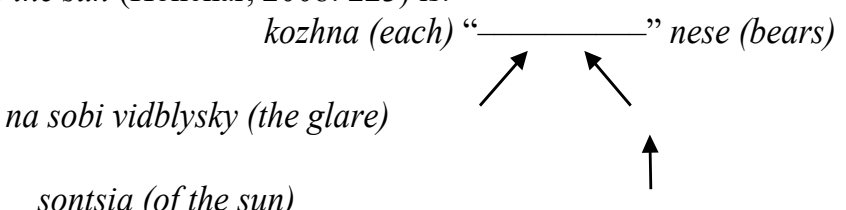

sontsia (of the sun)

It is expedient to describe the structure of a complex sentence with the help of their linear schemes in the form of graphs, as well as peculiar trees, the nodes of which are numbered parts of 


\section{Ukrainian sense. 2020. ISSN 2313-4437}

multicomponent complex sentences, and branches are syntactic connections between these parts. For example, the sentence Such a pity that we had not met, when I visited those places (Honchar, 2008: 232) has the linear scheme (graph.): (1) (2) (3).

Another graph will correspond to a multicomponent sentence, which reflects other syntactic connections between the components, for example: Sometimes it was thought: I am worthless if I am not able to help someone (Honchar, 2008: 232) - (2) (1)<smiles>[3H][Hg]</smiles>

The model of Larger-then-the-sentence is a sequence of sentences that form this syntactic unit. Here, the corresponding linguistic objects, i.e. sentences, as well as the relations and connections between them are translated into images of structurally significant components. The connection between the components of Larger-then-the-sentence can be catenarian (c), parallel (p), elliptical (e), parcial or divided (d) and circular (ci). The sentence as a separate syntactic unit can be denoted by the symbol S. For example, Larger-then-the-sentence The same can be said about the artists from Ukraine, such as Kuindzhi. They sang it from a distance. Because - as Gogol, as well as Dovzhenko in recent years - they saw its healing, sacred beauty from a distance (Honchar, 2008: 236) can also be presented in an analytical expression:

ci

\section{$\mathrm{S} \cong \mathrm{S} \subseteq \mathrm{S}$}

Larger-then-the-sentence, in which the relations between its components are implemented otherwise than in the one given, can be represented by an analytical expression, marking these relations in an appropriate way. For example, the model of Larger-then-the-sentence We are flying to Japan (a parliamentary delegation). The evening, we have to fly all night... Japan has already been above us (Honchar, 2008: 239) is:

ci

\section{$S^{p} S$ p $S$}

Only a parallel connection is present, for example, in Larger-then-the-sentence, which consists of two unextended sentences such as: Apple trees are blooming. Lilac is flowering (Honchar, 2008: 186). Its model will be as follows:

\section{$\mathrm{S}^{\mathrm{p}} \mathrm{S}$}

In the system of basic syntactic units, the text is at the same level as the super-phrase unity, but the structural parameters of the text, unlike the parameters of the super-phrase unity, are not clearly determined, and therefore structurally the text cannot be unambiguously defined. Different number of components can be its components, from one to a certain set, any unit of language. According to the definition proposed in this article, formally a text cannot be correlated only with a certain large syntactic structure because its volume can be limited by one sentence or one phrase, one word or even a single symbol, which there is, for example, one letter. Thus, the model of the text is a symbolic image of some set of basic syntactic units, which is given with the indication of the element of this set, i.e. the symbol of the unit or the symbol of those units from which the modelled text is constructed. In the model of the text it is advisable to use the actual linguistic symbolism (according to the English terms Text, Word, Constructions, Sentence and Larger-thenthe sentence): $\mathbf{T}$ - text, $\mathbf{W}$ - word form, $\mathbf{C}$ - word combination and word connection, $\mathbf{S}$ sentences, $\mathbf{L}$ - Larger-then-the sentence.

The basic text models are the following four models, consisting of only one of these components:

- word forms (W) - Coffeehouse (an inscription on the building); billboard);

- collocations and phrases $(\mathbf{C})$ - Work creatively; Hope and future (an inscription on the

- sentence (S) - Let's believe in ourselves! (an inscription on the billboard); 


\section{Ukrainian sense. 2020. ISSN 2313-4437}

- larger-then-the sentence (L) - STR will not build us a new person, will not form him - it is beyond its power. It would be good if it at least cleansed the seas, rivers, the atmosphere which is necessary for the normal existence of the human race. STR does not claim the educational functions (for all its omnipotence) (Honchar, 2008: 242).

Models of the Ukrainian text, represented by only one component, are as follows: $\mathbf{T}=(\mathbf{W})$; $\mathbf{T}=(\mathbf{C}) ; \mathbf{T}=(\mathbf{S}) ; \mathbf{T}=(\mathbf{L})$. Any of them can be supplemented and deployed, forming the derived models such as SS, SSL, LS and so on.

Conclusions. Thus, as evidenced by the analyzed material, the specificity of the syntax is clearly identified both in terms of its expression and in terms of content. The syntax is essentially inexhaustible in the material that fills it. Units of pre-syntactic levels of language can be set by a finite list (for example, phonemes), and it is impossible to build a list of syntactic units in general, because of their multiplicity, abundance. An attempt to clearly define a syntactic unit as one of the fundamental categories of syntax is made in this article. On the basis of the defined criteria, all syntactic units are divided into five classes: basic, substantive, derivative, analytical and analytical and searchable. A six-component system of basic syntactic units (a word form, a word combination, a word connection, a sentence, a text, larger-then-the sentence ) is formed, the criteria of formation of this system are offered. The process of the syntactic unit modelling is closely connected with its essential study. It is proposed to investigate the modelling of syntactic units of the modern Ukrainian language on the basis of two main operations: the operation of displaying a multiplicity of words on a multiplicity of their classes (for analytical and graphical models) and the operation of image contamination (for analytical models). The perspectives of studies: created initial units, their detailing, analytical and search units in connection with the emergence of new syntactic theories and approaches to the analysis of speech chains, as well as the initial models of the basic syntactic units on the basis of other basic models can be the object of separate research studies.

\section{REFERENCES}

Ahmanova, O. S. (1966). Slovar' lingvisticheskih terminov [Dictionary of linguistic terms]. Moscow: Sovetskaja enciklopedija [in Russian].

Beloshapkova, V.A. (1967). Slozhnoe predlozhenie v sovremennom russkom jazyke [A complex sentence in modern Russian]. Moscow: Prosveshhenie [in Russian].

Beliaev, Ju. I. (2003). Sintaksis sovremennogo russkogo literaturnogo jazyka [Syntax of the modern Russian literary language]. Kherson: Izd-vo Hersonskogo gosudarstvennogo universiteta [in Russian].

Bilodid, I. K. (Red.). (1972). Suchasna ukrainska literaturna mova. Syntaksys [Modern Ukrainian literary language. Syntax]. Kyiv: Naukova dumka [in Ukrainian].

Busel, V. T. (Red.). (2005). Velykyi tlumachnyi slovnyk suchasnoi ukrainskoi movy [Large explanatory dictionary of the modern Ukrainian language]. Kyiv; Irpen: VTF "Perun" [in Ukrainian].

Hanych, D. I. \& Oliinyk, I. S. (1985). Slovnyk linhvistychnykh terminiv [Dictionary of linguistic terms]. Kyiv: Vyshcha shkola [in Ukrainian].

Hodiul, V. P. (Red.). (2000). Informatyka ta obchysliuvalna tekhnika: korotkyi tlumachnyi slovnyk [Informatics and computer engineering: a short explanatory dictionary]. Kyiv: Lybid [in Ukrainian].

Honchar, O. T. (2008). Shchodennyky [Diaries]. (Vol. 3). Kyiv: Veselka [in Ukrainian].

Zahnitko, A. P. (1997). Typolohiia semantyko-syntaksychnykh vidnoshen [Typology of semantic-syntactic relations]. Vostochnoukraynskyi lynhvystycheskyi sbornyk - East Ukrainian Linguistic Collection, 3, 22-34 [in Ukrainian].

Zubkov, M. H. (2004). Ukrainska mova: universalnyi dovidnyk [Ukrainian language: universal reference book]. Kharkiv: Shkola [in Ukrainian].

Karpenko, Yu. O. (2006). Vstup do movoznavstva [Introduction to linguistics]. Kyiv: Akademiia [in Ukrainian]. 


\section{Ukrainian sense. 2020. ISSN 2313-4437}

Koroliova, V. (2016). Komunikatyvno-prahmatychna orhanizatsiia suchasnoi ukrainskoi dramy [Communicative and pragmatic organization of modern Ukrainian drama]. Dnipro: Lira [in Ukrainian].

Krotevych, Ye. V. \& Rodzevych, N. S. (1957). Slovnyk linhvistychnykh terminiv [Dictionary of linguistic terms]. Kyiv: Vyd-vo AN URSR [in Ukrainian].

Levickij, YU. A. (1983). Sintaksicheskaya sistema yazyka [Syntactic system of language]. Perm: Izd-vo Permskogo universiteta [in Russian].

Men'shikov, I. I. (1969). Kontaminirovannye obrazy kak sposob predstavleniya sintaksicheskih struktur [Contaminated images as a way of representing syntactic structures]. Avtomatizaciya informacionny rabot $i$ voprosy prikladnoj lingvistiki - Automation of information works and questions of applied linguistics, 1, 64-67 [in Russian].

Men'shikov, I. I. (1972). Model' kontaminirovannyh obrazov $v$ sintaksise [Model of contaminated images in syntax]. Dnepropetrovsk: DGU [in Russian].

Peterson, M. N. (1923). Ocherk sintaksisa russkogo jazyka [Essay on the syntax of the Russian language]. Moscow: Gosizdat [in Russian].

Popova, I. S. (2009). Diapazon osnovnykh syntaksychnykh odynyts suchasnoi ukrainskoi movy [The range of basic syntactic units of the modern Ukrainian language]. Linhvistychni doslidzhennia:zbirnyk naukovykh prats - Linguistic research: collection of scientific works, 140147 [in Ukrainian].

Popova, I. S. (2009). Fundamentalni katehorii metamovy ukrainskoho syntaksysu (odynytsia, zviazok, model) [Fundamental categories of metalanguage of Ukrainian syntax (unit, connection, model)]. Dnepropetrovsk: Vyd-vo DNU [in Ukrainian].

Popova, I. S. (2009). Syntaksychni parametry tekstu yak linhvistychnoho yavyshcha [Syntactic parameters of the text as a linguistic phenomenon]. Naukovyi visnyk Khersonskoho derzhavnoho universytetu - Scientific Bulletin of Kherson State University, 9, 47-50 [in Ukrainian].

Popova, I. S. (2013). Nadfrazna yednist u syntaksychni systemi suchasnoi ukrainskoi movy [Superphrase unity in the syntactic system of the modern Ukrainian language]. Skhidnoslovianska filolohiia. Movoznavstvo - East Slavic philology. Linguistics, 25, 18-27 [in Ukrainian].

Popova, I. S. (2013). Slovoforma v systemi syntaksychnykh odynyts suchasnoi ukrainskoi movy [Wordform in the system of syntactic units of the modern Ukrainian language]. Naukovi zapysky. Seriia "Filolohichna" - Proceedings. Philological Series, 39, 91-93 [in Ukrainian].

Popova, I. S. (2014). Pro osnovni operatsii linhvistychnoho modeliuvannia v syntaksysi [On the basic operations of linguistic modelling in syntax]. Ukrainskyi smysl - Ukrainian meaning, 7684 [in Ukrainian].

Popova, I. S. (2016). Typolohiia syntaksychnykh odynyts suchasnoi ukrainskoi movy [Typology of syntactic units of the modern Ukrainian language]. Ukrainskyi smysl - Ukrainian meaning, 300-309 [in Ukrainian].

Revzin, I. I. (1962). Osnovnye edinicy sintaksicheskogo analiza i ustanovlenie otnoshenij mezhdu nimi [Basic units of parsing and establishing relationships between them]. Strukturnotipologicheskie issledovanija - Structural and typological research (pp. 119-123). Moscow: Izd-vo AN SSSR [in Russian].

Rusanivskyi, V. M. \& Taranenko, O. O. (Red.). (2000). Ukrainska mova. Entsyklopediia [Ukrainian language. Encyclopedia]. Kyiv: Ukrainska entsyklopediia [in Ukrainian].

Russkaja grammatika [Russian grammar] (1980). (Vol. 2). Moscow: Nauka [in Russian].

Sirotinina, O. B. (1980). Lekcii po sintaksisu russkogo jazyka [Lectures on the syntax of the Russian language]. Moscow: Vysshaja shkola [in Russian].

Solganik, G. Ja. (1973). Sintaksicheskaja stilistika [Syntactic stylistics]. Moscow: Vysshaja shkola [in Russian].

Stoljarov, L. P., Pristajko, T. S., \& Popko, L. P. (2003). Bazovyj slova' lingvisticheskih terminov [Basic dictionary of linguistic terms]. Kiev: Izd-vo Gosudarstvennoj akademii rukovodjashhih kadrov kul'tury i iskusstv [in Russian]. 
Fortunatov, F. P. (1956). Izbrannye trudy [Selected works]. (Vol. 1). Moscow: Uchpedgiz [in Russian].

Shulzhuk, K. F. (2004). Syntaksys ukrainskoi movy [Syntax of the Ukrainian language]. Kyiv: Akademiia [in Ukrainian].

Jarceva, V. N. (Red.). (1990). Lingvisticheskij enciklopedicheskij slovar [Linguistic encyclopedic dictionary]. Moscow: Sovetskaja enciklopedija [in Russian].

\section{Анотація}

Постановка проблеми. У статті порушені актуальні питання синтаксису сучасної української мови, який $\epsilon$ вершинним рівнем організащії мови $i$ у компетенції якого перебувають власне мовленнєві ланцюги як комунікативні утворення, щуо $i$ забезпечують прочес спілкування. Незважаючи на різноманіття підходів до вивчення явищ мови, найважливішим у ї̈ теорії залишається поглиблений опис універсальних понять і категорій. До універсалій, як на нас, на рівні синтаксису належать такі фундаментальні категорії, як синтаксична одиниця, синтаксичний зв'язок та синтаксична модель, які, незважаючи на численні дослідження, продовжують перебувати в полі зору мовознавців.

мета cmammi. За мету в запропонованій науковій розвідиі поставлена спроба коректного витлумачення однієї з фундаментальних категорій, а саме синтаксичної одиниці, в контексті системного підходу до осмислення синтаксичного рівня мови 3 опертям на різні його аспекти - формально-синтаксичний, семантико-синтаксичний та функиійно-комунікативний.

Методи дослідження. $\quad$ прочесі обтрунтування категорійного статусу синтаксичної одиниці застосовано фундаментальні теоретико-методологійні принципи досліджень сучасного украӥнського $i$ загального мовознавства, зокрема положення про системність мовних і мовленнєвих явищ. Основним методологійним підтрунтям розкриття сутності синтаксичної одиниці (дефініиії, статусу, типології, прочесу моделювання) стали такі методи дослідження, як спостереження, описовий, аналіз словникових дефініцій, узагальнення, зіставлення, систематизація, трансформаційний та моделювання.

Основні результати дослідження. У статті подано огляд досягнутого на попередніх етапах лінгвістичних досліджень у трактуванні такого синтаксичного конструкта, як одиниия. У контексті термінологічної системи сучасного синтаксису проаналізовано наявні визначення синтаксичної одиниці як одного з основних синтаксичних понять та запропоновано ї̈ коректну дефініцію з найповнішим урахуванням структурних тафункиійних особливостей. Отже, синтаксична одиниия визначена як функиійно маркований і граматично впорядкований мовленнєвий ланщңюг, щзо є довільною змістово значущою послідовністю словоформ, навіть й окремою словоформою. Таке визначення дає змогу кваліфікувати як синтаксичну одиницю будь-яку мовленнєву побудову, де є план вираження (граматичні засоби зв'язку) та план змісту (інформація семантичного чи функційного характеру).

Оскільки характер граматичного впорядкування мовленнєвих ланщюгів, і їхні функиії, і ступінь лінгвістичної значущості різні як у плані їхнього змісту, так і в плані вираження, то постає потреба в градуюванні синтаксичних одинищь, передусім за значущістю ієрархічних відношень між ними. У множині синтаксичних одиниць української мови виділено чотири підмножини: базові, основні, похідні та периферійні (аналітичні та аналітико-пошукові). Базовими (своєрідними універсаліями) є дві одиниці - слово як елементарний, мінімальний лексичний компонент мовленнєвого ланцюга та конструкція як певна послідовність слів, щңо є тим чи тим мовленнєвим ланцюгом. Найважливішою ланкою системи синтаксичних одиниць постають основні одиниці, формування яких можливе лише з урахуванням певних критеріїв, параметрів: адекватність граматичному ладові української мови; функційне детермінування; максимально можливе узагальнення в межах виконуваних функиій; повнота і самодостатність; зв'язаність з іншими одиницями всієї системи. Пропонована система основних синтаксичних одиниьь охоплюе шість компонентів: 


\section{Ukrainian sense. 2020. ISSN 2313-4437}

словоформа, словосполучення, словоз'єднання, речення, текст, надфразна єдність. Словоформу витлумачено як структурно мінімальну синтаксичну одиницю, щуо функиіонує або як комунікативно значущий компонент певного мовленнєвого ланцңюга, або як самостійне синтаксичне утворення; словосполучення як поєднання двох чи більше повнозначних слів (словоформ) на основі лише підрядного зв'язку; словоз'єднання як поєднання двох чи більше повнозначних слів на основі сурядного зв'язку або інших семантико-граматичних відношень, що не є власне підрядним зв'язком; речення як певне предикативне синтаксичне утворення, щзо складається зі слова (чи його аналога) або синтаксично зв'язаної групи слів (чи їх аналогів) і виконує комунікативну функиію; текст як комунікативно значуще, формально ци змістово завершене мовленнєве утворення, побудоване з певною прагматичною настановою; надфразна єдність як поєднання двох i більше речень, що пов'язані між собою формальними лінгвістичними засобами лексичного чи граматичного характеру й об'єднані спільністю теми, настановою на змістову повноту окремого акту комунікаиії. Основні синтаксичні одинииі кваліфіковано як категорії концептуальні. Унаслідок дериваційної деталізації основних синтаксичних одиниць постають похідні одиниці. Вони є різними підкласами в межах певної синтаксичної конструкції відповідно до тих чи тих їхніх функційних $і$ структурних характеристик умежах певної синтаксичної конструкиії. Їхня система, пов'язана з оперативними категоріями, є рухомою й постійно видозмінюваною. Певне місие в системі синтаксичних одиниць посідають аналітичні одиниці, побудовані на основі категорій традииійного формально-граматичного синтаксису, та аналітико-пошукові, щзо виділені в контексті певних нових, оригінальних на противагу класичному синтаксисові концепщій.

Оскільки синтаксичні одиниці - це величезна, навіть теоретично незліченна сукупність різноманітних конструкцій, то це зумовило появу в практиці синтаксичного аналізу мовленнєвих ланцюгів особливого й оптимально ефективного методу - методу лінгвістичного моделювання. Актуалізовано в роботі три іпостасі поняття модель: структурний чи функційний аналог виучуваного явища; своєрідна метамова, тобто та система деяких правил, у межах яких дослідник вивчає граматику мови $і$ формулює результати своїх досліджень; певна лінгвістична одиниия. Із застосуванням двох операцій відображення та контамінування образів запропоновано зразки моделей (графічних або аналітичних, чи тих і тих) усіх основних синтаксичних одинищь.

Висновки і перспективи. Проаналізований матеріал ще раз засвідчує, що специфіка синтаксису чітко виявлена як у плані його вираження, так $і$ в плані змісту. У роботі чітко дефінійовано синтаксичну одиницю як одну з основних, фундаментальних категорій синтаксису, подано типологію ичи конструктів, запропоновано їх моделі. Об'єктом подальших досліджень тут можуть стати похідні одинииі, зокрема їхня деталізаиія, аналітико-пошукові одиниці у зв'язку з виникненням нових синтаксичних теорій та підходів до аналізу мовленнєвих ланцฺюгів, моделювання похідних одиниць украӥнської мови тощо.

Ключові слова: синтаксичний рівень мови, одиниця, синтаксична одиниця, дефініція синтаксичної одиниці, типологія синтаксичних одиниць, лінгвістичне моделювання, модель.

\section{Abstract}

Background. In the article the vital questions of syntax of the present-day Ukrainian language are touched, syntax represents the top stratum of language organization and in its competence there are its own speech chains as the communicative creations that guarantee a process of communication. In spite of the diversity of ways of approach to the study of language phenomena, the profound and thorough description of universal notions and categories remains the most important in its theory. We believe that at a level of syntax the language universals include such basic categories as the syntactic unit, the syntactic connection and the syntactic model that continue to remain within eyesight of the linguists despite the numerous investigations.

Purpose.The aim of the present scientific research is to make an attempt of the careful interpretation of one of the basic categories, namely the syntactic unit, in context of the system 


\section{Ukrainian sense. 2020. ISSN 2313-4437}

approach to the comprehension of the syntactic level of language as a base for the different aspects - formal and syntactic, semantic and syntactic, functional and communicative.

Methods. The process of substantiation of the categorial status of the syntactic unit involves the fundamental theoretical and methodological principles in the research of present-day Ukrainian and general linguistics, in particular the point of the systematic character of the language and speech phenomena. The following methods of investigation - observation, description, analysis of lexical definitions, generalization, comparison, systematization, transformation and modelling have become the main methodological substratum in opening the essence of the syntactic unit (its definition, status, typology, process of modelling).

Results. In the article it is given a review of achievements from the previous period of the linguistic studies in treating such a syntactic construct as a unit. In context of the terminological system of present-day modern syntax it is analysed the existent determinations of the syntactic unit as one of the basic syntactic notions, it is proposed the proper definition of the syntactic unit adjusted for the structural and functional peculiarities. Thus, the syntactic unit is defined as the speech chain that is grammatically regulated and marked in a functioned way, is represented by a free meaningful sequence of word forms, even by a separate word form. This determination gives an opportunity to qualify any speech structure with a plane of expression (the grammatical means of connection) and a plane of content (the information of semantic character or character marked in a functioned way) as the syntactic unit.

The character of the grammatical ordering of the speech chains and their functions, the degree of linguistic significance are different both in a plane of their content and in a plane of their expression, therefore it appears the necessity of gradation of the syntactic units, first and foremost, in the field of significance of hierarchical relations between them. It is distinguished four subsets of the plural number of the syntactic units in the Ukrainian language: basic, main, derivative and peripheral (analytical, analytical and search). Two units are basic (the peculiar language universals) - a word as an elementary, minimal lexical component of the speech chain and a structure as a definite sequence of words that also represents a kind of speech chain. The most important link in the system of the syntactic units is represented as the basic units, the formation of which is possible only with inclusion of the determined criteria, parameters: adequacy to the grammatical order of the Ukrainian language; determination formed in a functioned way; generalization within limits of performed functions is maximally possible; completeness and selfsufficiency; connectedness with other units of the whole system. The suggested system of basic syntactic units includes six components: word form, expression, word combination, sentence, text, larger-then-the-sentence unity. The word form is interpreted as a structurally minimal syntactic unit that functions either as a communicatively significant component of a certain speech chain, or as an independent syntactic formation; a phrase as a combination of two or more full words (word forms) based only on a subjunctive correlation; a word combination as a combination of two or more full words on the basis of a conjunctive correlation or other semantic-grammatical relations, which is not actually a subjunctive correlation; a sentence as a certain predicative syntactic formation consisting of a word (or its analogue) or a syntactically connected group of words (or their analogues) and performing a communicative function; the text as a communicatively significant, formally and semantically completed speech formation, built with a certain pragmatic purpose; larger-then-the-sentence as a combination of two or more sentences, which are connected by formal linguistic means of lexical or grammatical nature and united by a common theme, a guide to the content of a separate act of communication. The main syntactic units are defined as conceptual categories. Derivative units appear due to the derivational detailing of the main syntactic units. They are different subclasses within a certain syntactic construction according to their functional and structural characteristics within a certain syntactic construction. Their system, which is related to operational categories, is flexible and constantly changing. The analytical units, built on the basis of categories of traditional formal-grammatical syntax, and analytical-search units, which are emphasized in the context of certain new, original as opposed to classical syntax concepts occupy a certain place in the system of syntactic units. The fact that syntactic units are a 


\section{Ukrainian sense. 2020. ISSN 2313-4437}

huge, even theoretically endless set of various constructions has led to the syntactic analysis of speech chains of a special and optimally effective method - the method of linguistic modeling. In this work, three notions of the concept of model are foregrounded: structural or functional analogue of the studied phenomenon; a peculiar metalanguage or the system of some rules within which the researcher studies the grammar of the language and states the results of their research; and a certain linguistic unit. The samples of models (graphical or analytical, or both) of all basic syntactic units are proposed by using two operations of image-mapping and its contamination.

Discussion. The analyzed material once again shows that the specificity of the syntax is clearly identified both in terms of its expression and in terms of its content. The syntactic unit as one of the main, fundamental categories of syntax is clearly defined in the work, the typology of these constructs is given and their models are offered. The object of further research may be derived units, in particular their detailing, analytical and search units due to the fact that new syntactic theories and approaches to the analysis of speech chains, modelling of derived units of the Ukrainian language appear.

Keywords: syntactic level of language, unit, syntactic unit, definition of a syntactic unit, typology of syntactic units, linguistic modelling, model, larger-then-the-sentence. 